GA-A 14376

UC-77

\title{
STUDY OF TRITIUM PERMEATION THROUGH PEACH BOTTOM STEAM GENERATOR TUBES
}

by

L. YANG, W. A. BAUGH, and N. L. BALDWIN

Prepared under Contract EY-76-C-03-0167

Project Agreement No. 56 for the San Francisco Operations Office

U.S. Energy Research and Development Administration and the Electric Power Research Institute 


\section{DISCLAIMER}

This report was prepared as an account of work sponsored by an agency of the United States Government. Neither the United States Government nor any agency Thereof, nor any of their employees, makes any warranty, express or implied, or assumes any legal liability or responsibility for the accuracy, completeness, or usefulness of any information, apparatus, product, or process disclosed, or represents that its use would not infringe privately owned rights. Reference herein to any specific commercial product, process, or service by trade name, trademark, manufacturer, or otherwise does not necessarily constitute or imply its endorsement, recommendation, or favoring by the United States Government or any agency thereof. The views and opinions of authors expressed herein do not necessarily state or reflect those of the United States Government or any agency thereof. 


\section{DISCLAIMER}

Portions of this document may be illegible in electronic image products. Images are produced from the best available original document. 
7

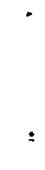

3. 
This report describes the equipment developed, samples tested, procedures used, and results obtained in the tritium permeation tests conducted on steam generator tubing samples, which were removed from the Peach Bottom Unit No. 1 reactor.

Peach Bottom was the first installation of a High-Temperature GasCooled Reactor (HTGR) in the United States. Power operation began in January 1967 and commercial operation on June 1, 1967. The plant was operated successfully through October 31, 1974, when it was shut down for decommissioning.

The Peach Bottom End-of-Life (PBEOL) Program, cosponsored by ERDA and EPRI, was initiated in March 1975. The prime objective of this program is to validate specific HTGR design codes and predictions by comparison of actual and predicted physics, thermal, fission product, and materials behavior in Peach Bottom. These design-methods verifications, to be completed in CY-77, utilize the data determined during three consecutive phases of the program, together with the data determined in a complementary program of Peach Bottom driver fuel element PIEs at ORNL. The three phases are (1) nondestructive fuel and circuit gamma scanning at the Peach Bottom site, (2) removal of Peach Bottom steam generator and primary circuit components, and (3) laboratory examinations of the removed components. 

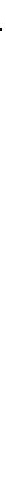

.

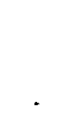


CONTENTS

ABSTRACT . . . . . . . . . . . . . . . . . . . . . . $\mathrm{i} i \mathrm{.}$

1. SuMMARY. . . . . . . . . . . . . . . . . . . . . . . 1

2. INTRODUCTION . . . . . . . . . . . . . . . . . 3

3. SAMPLE DESCRIPTION . . . . . . . . . . . . . . . 6

4. EXPERIMENTAL ARRANGEMENTS. . . . . . . . . . . . . . 8

5. EXPERIMENTAL PROCEDURES. . . . . . . . . . . . . . 11

5.1. TRITIUM SOURCE PREPARATION . . . . . . . . . . . 11

5.2. WELDING OF THE SAMPLE ASSEMBLY . . . . . . . . . . 11

5.3. MEASUREMENT OF TRITIUM PERMEATION RATE THROUGH THE AS-RECEIVED SAMPLES. • • • • • • • • • • • • • • • 13

5.4. MEASUREMENT OF TRITIUM PERMEATION RATE THROUGH SAMPLES AFTER THE REMOVAL OF THE SURFACE FILMS ON THE HELIUMCOOLANT SIDE AND THE STEAM SIDE. . . . . . . . . 15

5.5. MEASUREMENT OF TRITIUM PERMEATION RATE THROUGH SUPERHEATER SAMPLES FROM SIMULATED LARGE HTGR COOLANT. • • . • . . . 16

6. RESULTS, CONCLUSIONS, AND DISCUSSIONS. . . . . . . . . 17

6.1. AS-RECEIVED SAMPLES. . . . . . . . . . . . . 17

6.2. EFFECT OF SURFACE FILMS ON HELIUM-COOLANT SIDE . . . . . 17

6.3. EFFECT OF SURFACE FILMS ON STEAM SIDE. . . . . . . . 30

6.4. EFFECT OF TRITIUM CONCENTRATION. . . . . . . . . . . 30

6.5. COMPARISON OF CALCULATED WITH OBSERVED RATE OF TRITIUM RELEASE TO ENVIRONMENT FROM PEACH BOTTOM REACTOR . • . • 31

REFERENCES . . . . . . . . . . . . . . . . . . 35

\section{FIGURES}

4-1. Experimental arrangements for the study of tritium permeation through Peach Bottom steam generator tubes......... . 9

6-1. Tritium permeation rates of as-received Peach Bottom superheater samples. . . . . . . . . . . . . . . . . . 22

6-2. Tritium permeation rates of as-received Peach Bottom economizer samples . . . . . . . . . . . . . . . . . 23 
FIGURES (continued)

6-3. Tritium permeation rates of as-received Peach Bottom evaporator sample EV-I-26. . . . . . . . . . . . . . . 24

6-4. Effect of surface films on tritium permeation rates of Peach Bottom economizer sample EC-0-76 . . . . . . . . . 25

6-5. Effect of surface films on tritium permeation rates of Peach Bottom evaporator sample EV-I-26. . . . . . . . . 26

6-6. Effect of surface films on tritium permeation rates of Peach Bottom superheater sample SU-I-6 . . . . . . . . . 27

6-7. Effect of tritium concentration on tritium permeation rate of as-received Peach Bottom superheater sample SU-0-6 . . . . . 28

6-8. Effect of tritium concentration on tritium permeation rate of Peach Bottom superheater sample SU-I-6 after the removal of the surface deposit on the helium coolant side . . . . . . . 29

\section{TABLES}

3-1. Characteristics of Peach Bottom steam generator samples used for tritium permeation tests . . . . . . . . . . . . . . 7

5-1. Characteristics of the tritium sources used in tritium permeation tests on Peach Bottom steam generator tubes . . . 12

6-1. Tritium permeation rates of as-received samples. . . . . . 18

6-2. Effect of surface films on tritium permeation rates of Peach Bottom steam generator samples . . . . . . . . . 19

6-3. Tritium permeation rate of Peach Bottom superheater samples from large HTGR helium coolant . . . . . . . . . . . . . 21

6-4. Calculated Peach Bottom tritium release rate, with surface films on the helium coolant side in the as-received conditions . . . . . . . . . . . . . . . . . . . 32

6-5. Calculated Peach Bottom tritium release rate, with the asreceived surface films on the helium coolant side removed 


\section{SUMMARY}

The tritium permeation rates of two Incoloy-800 superheater tubing samples, two low-carbon steel economizer tubing samples, and one siliconlow-carbon steel evaporator tubing sample, obtained from the Peach Bottom HTGR steam generators at end-of-life were measured in their respective operating temperature ranges in the reactor. The tritium source was a helium-tritium mixture at $1.013 \times 10^{5} \mathrm{~Pa}(1 \mathrm{~atm})$ pressure, which contained tritium and impurities at partial pressures similar to that in the Peach Bottom reactor coolant at its operating pressure. The tritium permeating through the wall of each sample was swept out with either a helium-steam mixture or pure helium gas at $1.013 \times 10^{5} \mathrm{~Pa}(1 \mathrm{~atm})$ pressure, and trapped and measured with a liquid scintillation counter.

The measurements of the tritium permeation rates were made under the following conditions: (1) with the samples in the as-received conditions, (2) after the removal of the surface films formed on the primary-coolant (helium) side during reactor operation, and (3) after the removal of the surface films on both the helium-coolant side and the steam side. For the two Incoloy-800 superheater samples, the tritium permeation rates were also measured by using a tritium source simulating the expected composition of the large HTGR coolant.

The tritium permeation rates observed for the two Incoloy-800 superheater samples were in good agreement even though they operated at different temperatures in the Peach Bottom reactor. The same was true for the two low-carbon steel economizer samples. Removal of the surface film that formed on the helium-coolant side of the economizer during reactor operation had no appreciable effect on the tritium permeation rate. Removal of the surface film that formed on the helium-coolant side of the evaporator or the superheater, however, lowered the tritium permeation rate. It appears that the removal of these films allowed the formation of protective 
layers of low tritium permeation rates by a reaction between the impurities in the tritium source and Incoloy-800 or silicon-low-carbon steel. For all three types of samples studied, the surface films on the steam side lowered the tritium permeation rates significantly. For the two Incoloy-800 superheater samples, the increase of the tritium permeation rates with tritium concentration in the tritium source obeyed neither the linear nor the square root relationship. For an increase of tritium concentration from $6 \times 10^{2}$ to $1 \times 10^{4} \mu \mathrm{Ci} / \mathrm{std} \mathrm{m}^{3}$, the tritium permeation rate increased by a factor of about six when the sample had the surface film in the as-received state, and a factor of about ten after the removal of the as-received surface film.

On the basis of the measured tritium permeation rates for the asreceived samples and the surface areas and of the operating temperature ranges of the Peach Bottom steam generators, the tritium release rate from the helium coolant to the steam in the Peach Bottom reactor was calculated to be $1.28 \mathrm{Ci}$ per year for a linear distribution of temperature in all the steam generator sections. This is in good agreement with the observed value of about $1 \mathrm{Ci}$ per year.

The results showed that the tritium permeation rate is strongly dependent upon the surface conditions of the steam generator tubes and that the change of tritium permeation rate with tritium concentration in the source does not obey a simple relationship. Any calculation of tritium release rate from the helium coolant to the steam in an HTGR that uses tritium or hydrogen permeation data from the literature without first considering these factors could be misleading. 


\section{INTRODUCTION}

Inside the HTGR core, tritium can be formed by (1) ternary fission and (2) neutron activation of $\mathrm{He}-3$ in helium coolant gas, Li-6 and $\mathrm{Li}-7$ in graphite fuel blocks and reflectors, and B-10 in control rods and shields. The tritium formed can diffuse into the helium coolant and then permeate through the steam generator tube wall to the steam side, where exchange with $\mathrm{H}_{2} \mathrm{O}$ takes place. The resulting tritiated water is then released to the environment via water discharge from the plant.

In safety analysis for HTGR licensing, it is necessary to know the tritium release rate to the environment. This is usually accomplished by calculating the tritium permeation rate through the steam generator wall by using hydrogen permeation data (Ref. 1), making appropriate corrections for the mass difference between tritium and hydrogen, and taking into consideration the tritium-to-hydrogen ratio in the helium coolant. Assumptions are made that the permeation rate is inversely proportional to the thickness of the tube wall and that no surface film exists on either the helium side or the steam side of the steam generator tubes. In the actual case, these assumptions may not be true. Another approach for calculating tritium release from large HTGR core to the environment involves extrapolation from the observed Peach Bottomtritium release data (Ref. 2). The differences in the coolant impurity contents and the steam generator tube-surface conditions are ignored and assumptions have to be made on how the tritium permeation rate varies with tritium concentration and tube-wall thickness. The validity of these assumptions has not been proven, however.

The Peach Bottom reactor was in operation for a period of about seven years, and the release of tritium from the helium coolant to the water in the steam generator was periodically monitored. With the shutdown of the Peach Bottom reactor in October 1974, there was strong interest in carrying 
out postoperational measurements of the tritium permeation rates through the steam generator tube sections removed under the PBEOL program for the following reasons:

1. To provide experimental data on tritium permeation through steam generator tubes that had been in service for long periods of time.

2. To assess the effect of surface films formed on either the helium-coolant side or the steam side during reactor operation on tritium permeation rate by measuring the tritium permeation rate before and after these films are removed.

3. To verify that permeation rates measured in differential laboratory experiments can be successfully extrapolated to predict integral releases from operating HTGRs.

4. To improve the accuracy of predicting tritium release in large HTGRs by using the experimental data obtained.

Samples were obtained from the superheater, the evaporator, and the economizer sections of the Peach Bottom steam generator. Measurements of the tritium permeation rates were made in the operating temperature ranges of these sections, both in the as-received conditions and after the surface films were removed from the helium-coolant side, the steam side, or both. The tritium source used was a simulated Peach Bottom coolant at $1.013 \times 10^{5} \mathrm{~Pa}(1 \mathrm{~atm})$ pressure, which contains tritium and chemical impurities at partial pressures similar to that in the Peach Bottom coolant at its operating pressure $\left(2.330 \times 10^{6} \mathrm{~Pa}\right.$ or $\left.23 \mathrm{~atm}\right)$. For the Incoloy-800 superheater samples, measurements were also carried out with a simulated large HTGR coolant as the tritium source because Incoloy-800 will be used in large HTGR steam generators. No such measurements were performed with the evaporator and the economizer samples, which were made of silicon steel and low-carbon steel, respectively, since these materials are not being 
considered for large HTGR steam generator use (chromaloy steels will be used instead). Descriptions of the samples that were studied, experimental arrangements and procedures, experimental data, and results, conclusions, and discussions of the data appear in the following sections. 


\section{SAMPLE DESCRIPTION}

A total of five samples obtained from the Peach Bottom steam generator at end-of-life were identified for tritium permeation tests. These included two superheater samples (one from the inlet, one from the outlet), two economizer samples (one from the inlet, one from the outlet), and one evaporator sample (from the inlet). The characteristics of these samples are shown in Table $3-1$.

The as-received superheater sample had a compact black deposit (presumably carbonaceous) of about $10^{-4} \mathrm{~m}$ thickness on the external surface and a thin $\left(\sim 2.54 \times 10^{-5} \mathrm{~m}\right)$ reaction layer on the steam side. The as-received economizer and evaporator tubes had a thin, non-adherent black deposit $\left(\sim 2.54 \times 10^{-5} \mathrm{~m}\right)$ on the external surface and a thin $\left(\sim 2.54 \times 10^{-5} \mathrm{~m}\right)$ reaction layer (presumably magnetite) on the steam side. Special caution was exercised to protect these surface deposits during the welding of these samples to end caps and pedestals prior to the measurement of their tritium permeation rates. The structures and compositions of these surface deposits are subjects of investigation under the metallurgical task of the PBEOL Program. 
TABLE 3-1

CHARACTERISTICS OF PEACH BOTTOM STEAM GENERATOR SAMPLES USED FOR TRITIUM PERMEATION TESTS

\begin{tabular}{|c|c|c|c|c|c|c|}
\hline $\begin{array}{c}\text { Sample } \\
\text { Designation }\end{array}$ & $\begin{array}{c}\text { Location } \\
\text { Steam Generator }\end{array}$ & Material & $\begin{array}{l}\text { Length } \\
\left(10^{-2} \mathrm{~m}\right)\end{array}$ & $\begin{array}{c}\text { O.D. } \\
\left(10^{-2} \mathrm{~m}\right)\end{array}$ & $\begin{array}{c}\mathrm{I} \cdot \mathrm{D} \cdot \\
\left(10^{-2} \mathrm{~m}\right)\end{array}$ & $\begin{array}{c}\text { Effective } \\
\text { Area (a) } \\
\left(10^{-4} \mathrm{~m}^{2}\right)\end{array}$ \\
\hline$S U-I-6$ & Superheater inlet & Incoloy -800 & 18.16 & 1.905 & 1.270 & 90.16 \\
\hline$S U-0-6$ & Superheater outlet & Incoloy -800 & 16.89 & 1.905 & 1.270 & 83.86 \\
\hline $\mathrm{EC}-\mathrm{I}-87$ & Economizer inlet & Low carbon steel & 19.69 & 1.270 & 0.955 & 68.34 \\
\hline $\mathrm{EC}-0-76$ & Economizer outlet & Low carbon steel & 20.57 & 1.270 & 0.955 & 71.42 \\
\hline $\mathrm{EV}-\mathrm{I}-26$ & Evaporator inlet & $\begin{array}{l}\text { Low carbon silicon } \\
\text { steel(b) }\end{array}$ & 19.69 & 1.905 & 1.461 & 103.47 \\
\hline
\end{tabular}

(a) Effective area $=2 \pi 1\left(R_{2}-R_{1}\right) /\left(1 n R_{2}-1 n R_{1}\right)$, where $1=1$ ength, $R_{2}=0 \cdot D \cdot / 2$ and $R_{1}=I \cdot D \cdot / 2$. (b) $\mathrm{Si}=0.25$ wt $\%$ maximum. 


\section{EXPERIMENTAL ARRANGEMENTS}

The experimental arrangements for measuring the tritium permeation rates of Peach Bottom steam generator tubes are shown in Fig. 4-1.

The sample tube is welded to an Incoloy-800 end cap on one end and to an Incoloy-800 sample pedestal on the other end. The sample pedestal is then welded to an Incoloy-800 inner purge pedestal, which is in turn welded to an Incoloy-800 outer purge pedestal. The inlet and the outlet of the inner purge tubes, which carry the helium-steam mixture used for sweeping out the tritium that diffuses through the sample tube wall, are welded to the top of the inner purge pedesta1. To insure thorough sweeping, the outlet of the inner purge tube is extended to the top of the sample tube, while the inlet stays at the bottom. The outer purge line isolates the tritium source from the inner purge steam. Any tritium diffusing from the tritium source through the outer purge tube is swept out with helium. Without such an outer purge line, cross contamination from the tritium source is possible as a result of diffusion through the inner purge tube wall, which would thus introduce errors into the tritium permeation measurements. Specially designed purge flanges and copper gaskets are used to join the outer purge line to a helium source and the inner purge line to either a helium source or a helium-steam source. Any possible leaks in the valve systems between the tritium source and the inner purge line are isolated with helium purge.

The whole sample assembly is situated in a high-purity recrystallizedalumina (Morganite) permeation chamber inside a nichrome-resistance furnace. By adjusting the power inputs in the four separate windings of the furnace, the temperature of the sample, as indicated by three chromel-alumel thermocouples $\left(t c_{1}, t c_{2}, t c_{3}\right)$, can be kept uniform to within $\pm 2^{\circ} \mathrm{C}$ over its entire length. 


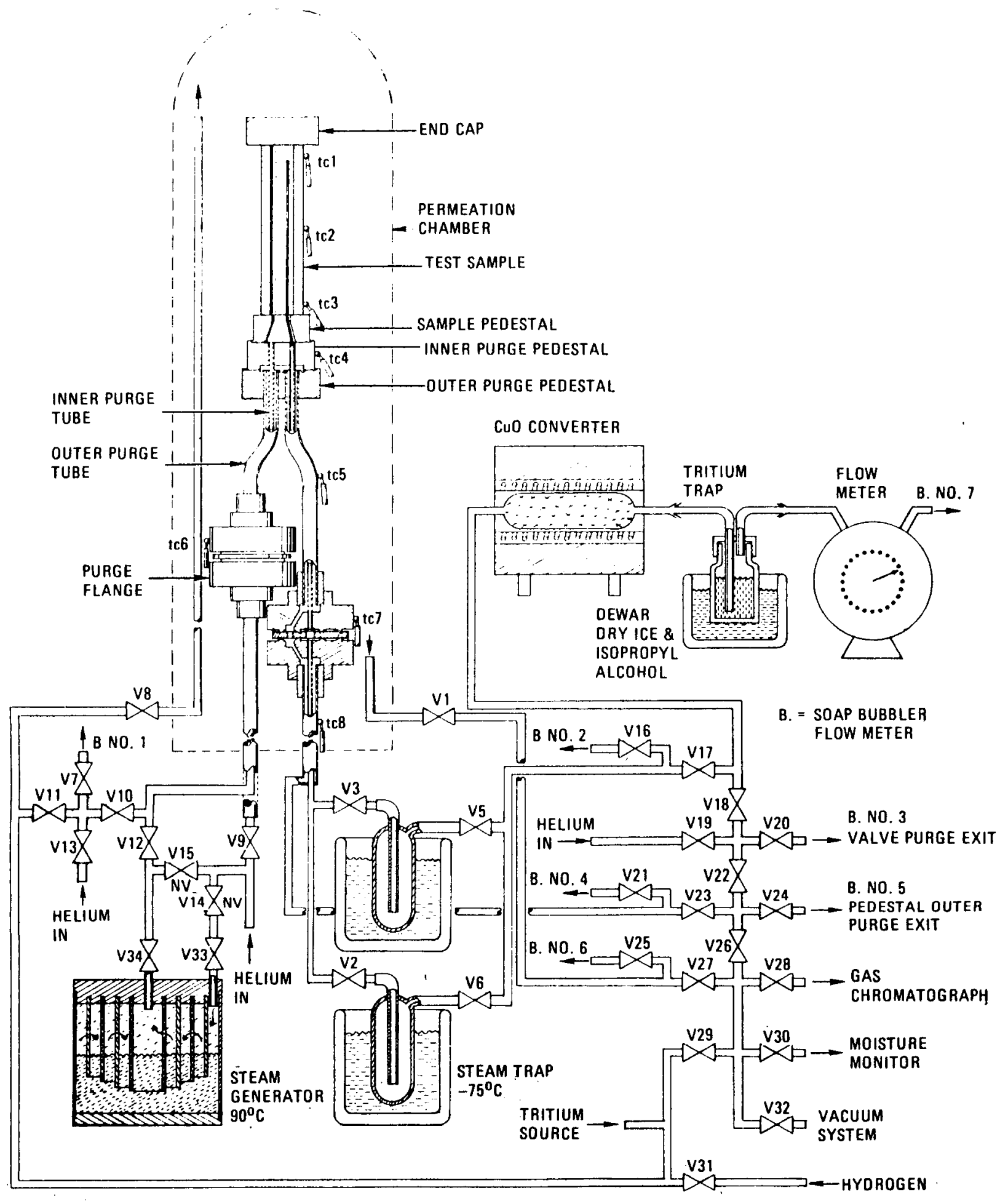

Fig. 4-1. Experimental arrangements for the study of tritium permeation through Peach Bottom steam generator tubes 
Manifolds at the bottom of the permeation chamber connect the system to (1) inlet and outlet of the tritium source, (2) inlet and outlet of the helium outer purge line, and (3) inlet and outlet of the helium-steam (or helium) inner purge line. The tritium source consists of helium gas at $1.013 \times 10^{5} \mathrm{~Pa}(1 \mathrm{~atm})$ pressure, which contains tritium and impurities $\left(\mathrm{H}_{2}\right.$, $\left.\mathrm{CH}_{4}, \mathrm{CO}, \mathrm{CO}_{2}\right)$ at specific activity and partial pressures similar to that in the Peach Bottom coolant (at $2.330 \times 10^{6} \mathrm{~Pa}$ or $23 \mathrm{~atm}$ ) or the large HTGR coolant (at $5.065 \times 10^{6} \mathrm{~Pa}$ or $50 \mathrm{~atm}$ ). The helium gas used in the outer and inner purge lines is $99.999 \%$ pure. In the cases where steam is added to the helium inner purge, the helium passes through a steam generator maintained at $90^{\circ} \mathrm{C}$, which contains copper baffles to insure that the helium is saturated with water vapor in the generator. The gas lines between the steam generator and the permeation chamber are heated to prevent condensation of the water vapor. The impurity contents in the tritium source can be measured with a gas chromatograph and a moisture monitor both before and after the tritium source passes through the permeation chamber. The helium-steam inner purge stream, after leaving the permeation chamber, passes through a cold trap to freeze the steam which now contains both water and tritiated water formed by the exchange of tritium with water. The helium leaving the cold trap flows through a CuO converter to oxidize the remaining tritium into tritiated water which is then collected in a liquid scintillation medium that has been cooled with an isopropyl alcoholdry ice mixture. The total volume and the flow rate of the exit helium gas during a run are measured with a rotary gas meter and a soap-bubble flow meter, respectively.

A vacuum system consisting of a liquid-nitrogen-trapped oil diffusion pump backed with a rotary mechanical pump is connected to the system for evacuating the gas lines and outgassing the sample prior to each run. A hydrogen source is also connected to the system, which is used to remove the oxide films that have formed on the sample surface during mechanical polishing or the oxide film that is present on the steam side of the sample. 


\section{EXPERIMENTAL PROCEDURES}

\subsection{TRITIUM SOURCE PREPARATION}

Tritium gas sealed in a glass ampoule was procured from Oak Ridge National Laboratory. The received ampoule containing about $2 \mathrm{Ci}$ of tritium was diluted with high-pressure helium of $99.999 \%$ purity to form a helium-tritium stock mixture containing about $5 \times 10^{5}$ microcuries of tritium per standard $\mathrm{m}^{3}$. A small portion of this stock mixture was mixed with high-pressure helium containing the desired concentrations of impurities (procurred from Matheson Company) to form the required tritium source.

Two types of tritium sources were prepared. The first had tritium activity and impurity contents similar to that in the Peach Bottom coolant (Ref. 3). The second had tritium activity and impurity contents similar to the design values for the large HTGR coolant (Ref. 4). Pertinent information on these two types of tritium sources used in the present study is summarized in Table 5-1.

\subsection{WELDING OF THE SAMPLE ASSEMBLY}

A11 the sample tubes received were contaminated with fission products, mainly the cesium isotopes. Special radiological safety considerations were necessary in handling these samples. To prepare for the welding of the ends of each sample tube to the end cap and the sample pedestal, the ends were cleaned mechanically for a distance of about $3.175 \times 10^{-3} \mathrm{~m}(1 / 8 \mathrm{in.})$ in a ventilated glove box. One end was TIG welded to the Incoloy-800 end cap and the other end was TIG welded to the sample pedestal. The sample pedestal was then TIG welded to the purge pedestal assembly to which the inner and the outer purge tubes had already been welded. All the welding operations were carried out in a glove box in helium, with the sample tube 
TABLE $5-1$

CHARACTERISTICS OF THE TRITIUM SOURCES USED IN TRITIUM PERMEATION TESTS ON PEACH BOTTOM STEAM GENERATOR TUBES

\begin{tabular}{|c|c|c|c|c|}
\hline & \multicolumn{2}{|c|}{$\begin{array}{c}\text { Simulation of Peach Bottom } \\
\text { Coolant }\end{array}$} & \multicolumn{2}{|c|}{$\begin{array}{l}\text { Simulation of Large HTGR } \\
\text { Coolant }\end{array}$} \\
\hline & $\begin{array}{c}\text { In Reactor at } \\
2.330 \times 10^{6} \mathrm{~Pa} \\
\text { or } 23 \text { atm } \\
\text { Operating Pressure }\end{array}$ & $\begin{array}{l}\text { Source } \\
\text { Prepared }\end{array}$ & $\begin{array}{l}\text { In Reactor at } \\
5.065 \times 10^{6} \mathrm{~Pa} \\
\text { or } 50 \text { atm } \\
\text { Operating Pressure }\end{array}$ & $\begin{array}{l}\text { Source } \\
\text { Prepared }\end{array}$ \\
\hline $\begin{array}{l}\text { Tritium specific activity } \\
\quad\left(\mu \mathrm{C} i / \mathrm{m}^{3}\right)\end{array}$ & $5.8 \times 10^{2}$ & $6 \times 10^{2}$ & $1 \times 10^{4}$ & $1 \times 10^{4}$ \\
\hline \multicolumn{5}{|l|}{$\begin{array}{l}\text { Impurities }(0.101 \mathrm{~Pa} \text { or } \\
\text { microatm })\end{array}$} \\
\hline $\mathrm{H}_{2}$ & 230 & 200 & 1500 & 1450 \\
\hline $\mathrm{N}_{2}$ & 23 & 27 & 50 & 54 \\
\hline $\mathrm{CH}_{4}$ & 23 & 22 & 50 & 50 \\
\hline $\mathrm{CO}$ & 12 & 11 & 50 & 48 \\
\hline $\mathrm{CO}_{2}$ & 2.3 & 2.7 & 5 & 5 \\
\hline $\mathrm{H}_{2} \mathrm{O}$ & 0.23 & $<1$ & 5 & 5 \\
\hline $\mathrm{O}_{2}$ & 0 & $<0.5$ & 0 & $<0.5$ \\
\hline
\end{tabular}


held in a rotating holder. The welded sample assembly was then joined to the rest of the permeation system through specially designed flanges (see Fig. 4-1).

5.3. MEASUREMENT OF TRITIUM PERMEATION RATE THROUGH THE AS-RECEIVED SAMPLES

After the sample assembly was installed in the permeation chamber, the chromel-alumel thermocouples were spot-welded to the sample surface and the pedestals (see Fig. 4-1). The $\mathrm{Al}_{2} \mathrm{O}_{3}$ envelope was then lowered over the sample assembly and joined to the base of the permeation chamber by an " $O$ " ring Cajon fitting. The permeation chamber and all the gas lines (except the steam generator) were evacuated to a residual gas pressure of less than $1.33 \times 10^{-3} \mathrm{~Pa}\left(10^{-5}\right.$ torr). The steam generator and the outer purge line were then purged with helium and the nichrome-resistance furnace (not shown in Fig. 4-1) was lowered over the $\mathrm{Al}_{2} \mathrm{O}_{3}$ envelope. The sample temperature was raised to the highest value for which the tritium permeation rate was to be measured. At the same time, the helium-steam mixture was admitted into the inner purge line, passing through the inside of the sample tube, the cold trap, the CuO converter, and the flowmeter.

The sample was outgassed for a period of four hours. Afterward it was cooled to room temperature in vacuum and the tritium source was admitted into the permeation chamber. The inner purge tritium-steam mixture was allowed to flow for a period of four hours. The condensate in the cold trap and the cooled liquid scintillation fluid in the tritium trap were checked for tritium activity. The absence of tritium activity above background indicated little or no leakage in the sample, the welds, and the copper gasket of the purge flanges, and showed the effectiveness of the outer purge system.

The temperature of the sample was then raised to the desired value. The system was allowed to equilibrate for at least 16 hours before trapping of the tritium in the helium-steam purge stream was begun. Usually two successive trappings were made, with each lasting from two to four hours. 
In a few cases, the trapping was allowed to run overnight to insure that the permeation process had reached a steady state.

After the completion of each trapping, both the steam condensate in the cold trap and the liquid scintillation fluid in the tritium trap were collected and each was counted for tritium activity by liquid scintillation techniques. The amount of tritium present, expressed in microcuries ( $\mu \mathrm{C} i$ ), was calculated from the counting rate (in counts per minute, or cpm) by the equation:

$$
\text { Amount of tritium in microcuries }=\frac{(\mathrm{dpm})}{2.22 \times 10^{6}}=\frac{(\mathrm{cpm})}{\mathrm{y} \cdot 2.22 \times 10^{6}} \text {, }
$$

where $\quad y=$ counting efficiency $=0.357$, as determined with a tritium standard for the counting geometry used,

$2.22 \times 10^{6}=$ conversion factor from disintegration per minute (dpm) to microcuries of tritium.

The tritium permeation rate of the sample was calculated by the equation:

$$
\begin{aligned}
& \text { Tritium permeation rate }=\frac{(\mu \mathrm{C} i)_{1}+(\mu \mathrm{C} i)_{2}}{\mathrm{At}}, \\
& \left(\mu \mathrm{Ci} / \mathrm{m}^{2}, \mathrm{hr}\right)
\end{aligned}
$$

where $(\mu \mathrm{C} i)_{1}=$ tritium in steam condensate in microcuries, *

$(\mu \mathrm{Ci})_{2}=$ tritium in cooled liquid scintillation fluid in tritium trap in microcuries,

$A=$ effective area of the sample in $\mathrm{m}^{2}$ (see Table 3-1),

$t=$ time of trapping in hours.

For each sample, the tritium permeation rate was measured at a number of temperatures in the temperature ranges indicated as follows:

*For al1 the cases studied, more than $90 \%$ of the tritium activity was in the steam condensate, indicating rapid exchange between tritium and water. 


$\begin{array}{ll}\text { Superheater } & 673 \mathrm{~K}-973 \mathrm{~K} \\ \text { Economizer } & 493 \mathrm{~K}-623 \mathrm{~K} \\ \text { Evaporator } & 573 \mathrm{~K}-693 \mathrm{~K}\end{array}$

The measurements of tritium permeation rate through the superheater samples were made at temperatures much higher than their maximum operating temperature in the Peach Bottom reactor $(973 \mathrm{~K}$ versus $853 \mathrm{~K}$ ) in order to provide information that may be useful to large HTGR design consideration.

\subsection{MEASUREMENT OF TRITIUM PERMEATION RATE THROUGH SAMPLES AFTER THE REMOVAL OF THE SURFACE FILMS ON THE HELIUM-COOLANT SIDE AND THE STEAM SIDE}

For one of each of the three types of sample tubes received, studies were carried out on the effect of surface films on tritium permeability.

For the economizer sample EC-0-76, the tritium permeation rate was measured after the removal of the surface film on the helium-coolant side, and then measured again after the surface film on the steam side was also removed. For evaporator sample EV-I-26, the tritium permeation rate was measured after the removal of the surface films on both the helium-coolant side and the steam side, and measurements were made again after the steamside film was restored. Subsequently, more measurements were made after the coolant-side surface was polished and then machined to remove about $2.54 \times 10^{-5} \mathrm{~m}(1 \mathrm{mil})$. For the superheater sample (SU-I-6), the measurement sequence was similar to that for the economizer sample EC-0-76, except that the steam-side film was finally restored and the tritium permeation rate measured again.

To remove the surface film on the coolant side, all the welds were coated with a thin layer of paraffin wax. The sample was then cleaned electrolytically in $10 \% \mathrm{NaOH}$, washed in water, and electropolished in a commercial electropolishing solution. During the electropolishing, the sample was removed intermittently from the solution, rinsed in water, and wiped with lint-free paper to see whether all the black surface film had 
been removed. The electropolishing operation was continued until all the black film disappeared. The sample was then polished with 4 " 0 " emery paper to remove any oxide film formed on the surface by the electropolishing reactions. Subsequently, the wax coating that was used to protect the welds was mechanically removed and the sample was rinsed in xylene and ultrasonically cleaned in water to remove any trace of wax and polishing grits. The sample was then installed in the permeation chamber. After evacuation, the outside surface of the sample was heated in hydrogen for four hours at the highest temperature planned for the experiment in order to remove any oxide film formed during the handling of the sample. The hydrogen was then pumped off and the measurement of the tritium permeation rate was carried out according to the procedures described in the previous section.

To remove the oxide film on the steam side, the sample was heated with hydrogen flowing through its inside for 48 hours at the highest temperature planned for the experiment. After the hydrogen was removed by evacuation, the tritium permeation rate was measured according to the procedures described in the previous section, with the exception that helium (99.999\% purity) instead of helium-steam mixture was used as the innerpurge-1ine gas. When needed, the oxide film on the steam side could be restored by changing the inner-purge-line gas from helium to helium-steam mixture.

\subsection{MEASUREMENT OF TRITIUM PERMEATION RATE THROUGH SUPERHEATER SAMPLES FROM SIMULATED LARGE HTGR COOLANT}

Since Incoloy-800 superheaters will be used in large HTGRs, the tritium permeation rates through the two Peach Bottom superheater samples were also measured with a tritium source having tritium activity and impurity partial pressures similar to that in the large HTGR coolant (see Table 5-1). The measurement procedures used were the same as those described above. 


\section{RESULTS, CONCLUSIONS, AND DISCUSSIONS}

The experimental results are listed in Tables 6-1 through 6-3. In Figs. 6-1 through 6-8, the measured permeation rates (in $\mu \mathrm{Ci} / \mathrm{m}^{2}, \mathrm{hr}$ ) are plotted versus the reciprocals of the absolute temperatures under which these rates were determined. In addition to the best-fit lines for the data points, the $90 \%$ confidence limits are also shown and the Arrhenius equations representing the best-fit lines are included in these figures. From these experimental results the following conclusions can be drawn.

\subsection{AS-RECEIVED SAMPLES}

There is no significant difference between the permeation rates of the two superheater samples (Fig. 6-1). The same is true for the two economizer samples (Fig. 6-2). This demonstrates the reproducibility of the tritium permeation mechanism for these materials even though they operated at different temperatures in the Peach Bottom reactor.

\subsection{EFFECT OF SURFACE FILMS* ON HELIUM-COOLANT SIDE}

The surface film formed on the helium-coolant side of the economizer sample (low-carbon steel) during its operation in the Peach Bottom reactor does not seem to have a significant effect on tritium permeation rate (Fig. 6-4, lower line), presumably because the surface film is porous. Removal of the as-received surface film on the helium-coolant side of the evaporator sample (silicon-low-carbon steel) or the superheater sample (Incoloy-800), however, lowers the tritium permeation rate (Fig. 6-5, lower line and Fig. 6-6, lower line). This is rather unexpected since it is generally believed that a surface film will either impede the permeation

*The morphologies, structures, and compositions of these films will be described in reports dealing with the metallurgical evaluations of Peach Bottom steam generator tubes under the PBEOL Program. 
TABLE 6-1

TRITIUM PERMEATION RATES OF AS-RECEIVED SAMPLES ${ }^{(a)}$

\begin{tabular}{|c|c|c|c|}
\hline $\begin{array}{l}\text { Test } \\
\text { No. }\end{array}$ & $\begin{array}{c}\text { Sample } \\
\text { Designation }\end{array}$ & $\begin{array}{c}\text { Temperature } \\
(\mathrm{K})\end{array}$ & $\begin{array}{c}\text { Tritium Permeation Rate } \\
\left(\mu \mathrm{C} i / \mathrm{m}^{2}, \mathrm{hr}\right)\end{array}$ \\
\hline 3 & SU-I-6 & 673 & $1.19(-1), 1.48(-1)$ \\
\hline 4 & & 773 & $4.34(-1), 4.75(-1)$ \\
\hline 5 & & 873 & $1.04(0), 8.28(-1)$ \\
\hline 6 & & 973 & $1.29(0), 1.47(0)$ \\
\hline 8 & $S U-0-6$ & 673 & $9.25(-2), 9.33(-2)$ \\
\hline 9 & & 773 & $4.35(-1), 4.83(-1)$ \\
\hline 10 & & 873 & $1.75(0), 1.69(0)$ \\
\hline 11 & & 973 & $2.90(0), \quad 2.68(0)$ \\
\hline 15 & $\mathrm{EC}-\mathrm{I}-87$ & 494 & $8.40(-3)$ \\
\hline 16 & & 564 & $1.40(-2), 170(-2)$ \\
\hline 17 & & 625 & $\begin{array}{l}6.61(-2), 6.35(-2), \\
6.29(-2)(c)\end{array}$ \\
\hline 18 & EC-0-76 & 493 & $1.28(-2)$ \\
\hline 19 & & 566 & $3.31(-2), 3.67(-2)$ \\
\hline 20 & & 563 & $3.09(-2)$ \\
\hline 21 & & 623 & $\begin{array}{l}6.90(-2), 6.51(-2) \\
5.80(-2)(c)\end{array}$ \\
\hline 22 & & 563 & $2.26(-2), 2.06(-2)$ \\
\hline 23 & & 523 & $1.72(-2), 1.38(-2)$ \\
\hline 24 & $E V-I-26$ & 573 & $4.55(-2), 4.75(-2)$ \\
\hline 25 & & 634 & $1.53(-1), 1.37(-1)$ \\
\hline 26 & & 694 & $3.84(-1), 3.59(-1)$ \\
\hline
\end{tabular}

(a) All tests were carried out with simulated Peach Bottom helium coolant outside the tubular sample (total pressure = $1.013 \times 10^{5} \mathrm{~Pa}$ or $1 \mathrm{~atm}$ ) and helium-steam mixture inside (total pressure $=1.013 \times 10^{5} \mathrm{~Pa}$ or $1 \mathrm{~atm}$, steam pressure $=6.66-$ $8.00 \times 10^{4} \mathrm{~Pa}$ or $500-600$ torr). The simulated Peach Bottom coolant has a tritium activity of $6 \times 10^{2} \mu \mathrm{Ci} / \mathrm{Std} \mathrm{m}^{3}$ and impurity partial pressures (in $0.101 \mathrm{~Pa}$ or microatm) of $\mathrm{H}_{2}$ 200, $\mathrm{CO} 11, \mathrm{~N}_{2} 27, \mathrm{CO}_{2} 2.7, \mathrm{CH}_{4} 22, \mathrm{H}_{2} \mathrm{O}<1, \mathrm{O}_{2}<0.5$.

(b) The tritium permeation rate is calculated on the basis of the effective surface area of the sample. The numbers in parentheses represent an exponent of 10 .

(c) The third measurement was carried out by using an extended tritium collection time (16 hours versus 2 hours for the other measurements). 
TABLE 6-2

EFFECT OF SURFACE FILMS ON TRITIUM PERMEATION RATES OF PEACH BOTTOM STEAM GENERATOR SAMPLES ${ }^{(a)}$

\begin{tabular}{|c|c|c|c|c|}
\hline $\begin{array}{l}\text { Test } \\
\text { No. }\end{array}$ & $\begin{array}{c}\text { Sample } \\
\text { Designation }\end{array}$ & Surface Condition & $\begin{array}{c}\text { Temperature } \\
(\mathrm{K})\end{array}$ & $\begin{array}{l}\text { Tritium Permeation Rate } \\
\left(\mu \mathrm{Ci} / \mathrm{m}^{2}, \mathrm{hr}\right)\end{array}$ \\
\hline 27 & EC-0-76 & Coolant-side film removed & 493 & $1.06(-2)$ \\
\hline 28 & & & 493 & $8.19(-3)^{(b)}$ \\
\hline 29 & & & 563 & $3.40(-2), 3.80(-2)$ \\
\hline 30 & & & 630 & $8.29(-2), 8.90(-2)$ \\
\hline 31 & $\mathrm{EC}-0-76$ & $\begin{array}{l}\text { Coolant-side and steam-side films both } \\
\text { removed }\end{array}$ & 513 & $9.67(-2), 7.94(-2)$ \\
\hline 32 & & & 562 & $2.44(-1), 2.43(-1)$ \\
\hline 33 & & & 628 & $7.33(-1), 7.10(-1)$ \\
\hline 37 & $E V-I-27$ & $\begin{array}{l}\text { Coolant-side and steam-side films both } \\
\text { removed }\end{array}$ & 631 & $7.14(-1), 6.73(-1)$ \\
\hline 38 & & & 692 & $2.06(0), \quad 1.92 .(0)$ \\
\hline 39 & EV-I-26 & Steam-side film restored & 693 & $6.32(-2), 9.09(-2)$ \\
\hline 40 & & & 693 & $8.63(-2), 9.28(-2)$ \\
\hline 41 & & & 633 & $2.64(-2), 2.66(-2)$ \\
\hline 49 & $E V-I-26$ & $\begin{array}{l}\text { Coolant-side surface cleaned further by } \\
\text { polishing; steam-side film intact }\end{array}$ & 633 & $2.53(-2), 2.83(-2)$ \\
\hline 50 & & & 693 & $1.14(-1), 1.30(-1)$ \\
\hline 51 & & & 573 & $9.40(-3), 8.24(-3)$ \\
\hline 62 & $E V-I-26$ & $\begin{array}{l}\text { Coolant-side surface removed } 1 \mathrm{mil} \\
\text { mechanically; steam-side film intact }\end{array}$ & 573 & $9.35(-3), 5.36(-3)$ \\
\hline 63 & & & 693 & $1.46(-1), 1.37(-1)$ \\
\hline
\end{tabular}


TABLE 6-2 (Continued)

\begin{tabular}{|c|c|c|c|c|}
\hline $\begin{array}{l}\text { Test } \\
\text { No. }\end{array}$ & $\begin{array}{c}\text { Sample } \\
\text { Designation }\end{array}$ & Surface Condition & $\begin{array}{l}\text { Temperature } \\
(\mathrm{K})\end{array}$ & $\begin{array}{l}\text { Tritium Permeation Rate } \\
\qquad\left(\mu \mathrm{Ci} / \mathrm{m}^{2}, \mathrm{hr}\right)\end{array}$ \\
\hline 52 & $S U-I-6$ & Coolant-side film removed & 773 & $2.25(-2), 1.36(-2)$ \\
\hline $52 \mathrm{~B}$ & & & 773 & $2.05(-2), 1.62(-2)$ \\
\hline 53 & & & 871 & $3.18(-2), 3.09(-2)$ \\
\hline 54 & & & 973 & $1.39(-1), 1.09(-1)$ \\
\hline 55 & $S U-I-6$ & $\begin{array}{l}\text { Coolant-side and steam-side films both } \\
\text { removed }\end{array}$ & 673 & $6.33(-2), 5.31(-2)$ \\
\hline 56 & & & 873 & $6.63(-1), 6.33(-1)$ \\
\hline 57 & $\mathrm{SU}-\mathrm{I}-6$ & Steam-side film restored & 873 & $2.92(-2), 2.64(-2)$ \\
\hline
\end{tabular}

(a) Measurements were made with the same simulated Peach Bottom helium coolant outside the tubular sample (at $1.013 \times 10^{5} \mathrm{~Pa}$ or $1 \mathrm{~atm}$ pressure) as that used for the measurements shown in Table 5-1. For cases where only the helium-coolant-side film was removed, the inside of the sample was exposed to a mixture of helium plus steam (total pressure $=1.013 \times 10^{5} \mathrm{~Pa}$ or $1 \mathrm{~atm}$, steam pressure $=6.66-8.00 \times 10^{4} \mathrm{~Pa}$ or $500-600$ torr). For cases where both the coolantside film and the steam-side film were removed, the inside of the sample was exposed only to helium.

(b) The measuring was carried out by using an extended tritium collection time (16 hours versus 2 hours for the other measurements). 
TABLE 6-3

TRITIUM PERMEATION RATE OF PEACH BOTTOM SUPERHEATER SAMPLES FROM LARGE HTGR HELIUM COOLANT (a)

\begin{tabular}{|c|c|c|c|c|}
\hline $\begin{array}{l}\text { Test } \\
\text { No. }\end{array}$ & $\begin{array}{c}\text { Sample } \\
\text { Designation }\end{array}$ & Surface Condition & $\begin{array}{c}\text { Temperature } \\
(\mathrm{K})\end{array}$ & $\begin{array}{l}\text { Tritium Permeation Rate } \\
\left(\mu_{\mathrm{Ci}} / \mathrm{m}^{2}, \mathrm{hr}\right)\end{array}$ \\
\hline 42 & $S U-0-6$ & $\begin{array}{l}\text { As-received, after } \\
\text { Test No. } 11\end{array}$ & 673 & $6.20(-1), 6.62(-1)$ \\
\hline 43 & & & 773 & $2.89(0), \quad 2.94(0)$ \\
\hline 44 & & & 873 & $9.23(0), \quad 9.23(0)$ \\
\hline 45 & & & 973 & $1.42(1), 1.57$ (1) \\
\hline 46 & & & 973 & $1.84(1), 1.32$ (1) \\
\hline 58 & SU-I-6 & $\begin{array}{l}\text { Coolant-side film } \\
\text { removed, after } \\
\text { Test No. } 57\end{array}$ & 673 & $8.92(-2), 1.00(-1)$ \\
\hline 59 & & & 773 & $1.91(-1), 2.24(-1)$ \\
\hline 60 & & & 873 & $3.09(-1), 4.15(-1)$ \\
\hline 61 & & & 973 & $1.20(0), 1.24(0)$ \\
\hline
\end{tabular}

(a) Measurements were made with simulated large HTGR helium coolant outside the tubular sample at $\left(1.013 \times 10^{5} \mathrm{~Pa}\right.$ or $1 \mathrm{~atm}$ pressure) and helium plus steam (total pressure = $1.013 \times 10^{5} \mathrm{~Pa}$ or $1 \mathrm{~atm}$, steam pressure $=500-600$ torr). The simulated large HTGR coolant has a tritium activity of $1 \times 10^{4} \mu \mathrm{Ci} / \mathrm{std} \mathrm{\textrm {m } ^ { 3 }}$ and impurity partial pressures (in $0.101 \mathrm{~Pa}$ or microatm) of $\mathrm{H}_{2} 1450, \mathrm{~N}_{2} 54, \mathrm{CH}_{4} 50, \mathrm{CO} 50, \mathrm{CO}_{2} 50, \mathrm{H}_{2} \mathrm{O} 5, \mathrm{O}_{2}<0.5$. 


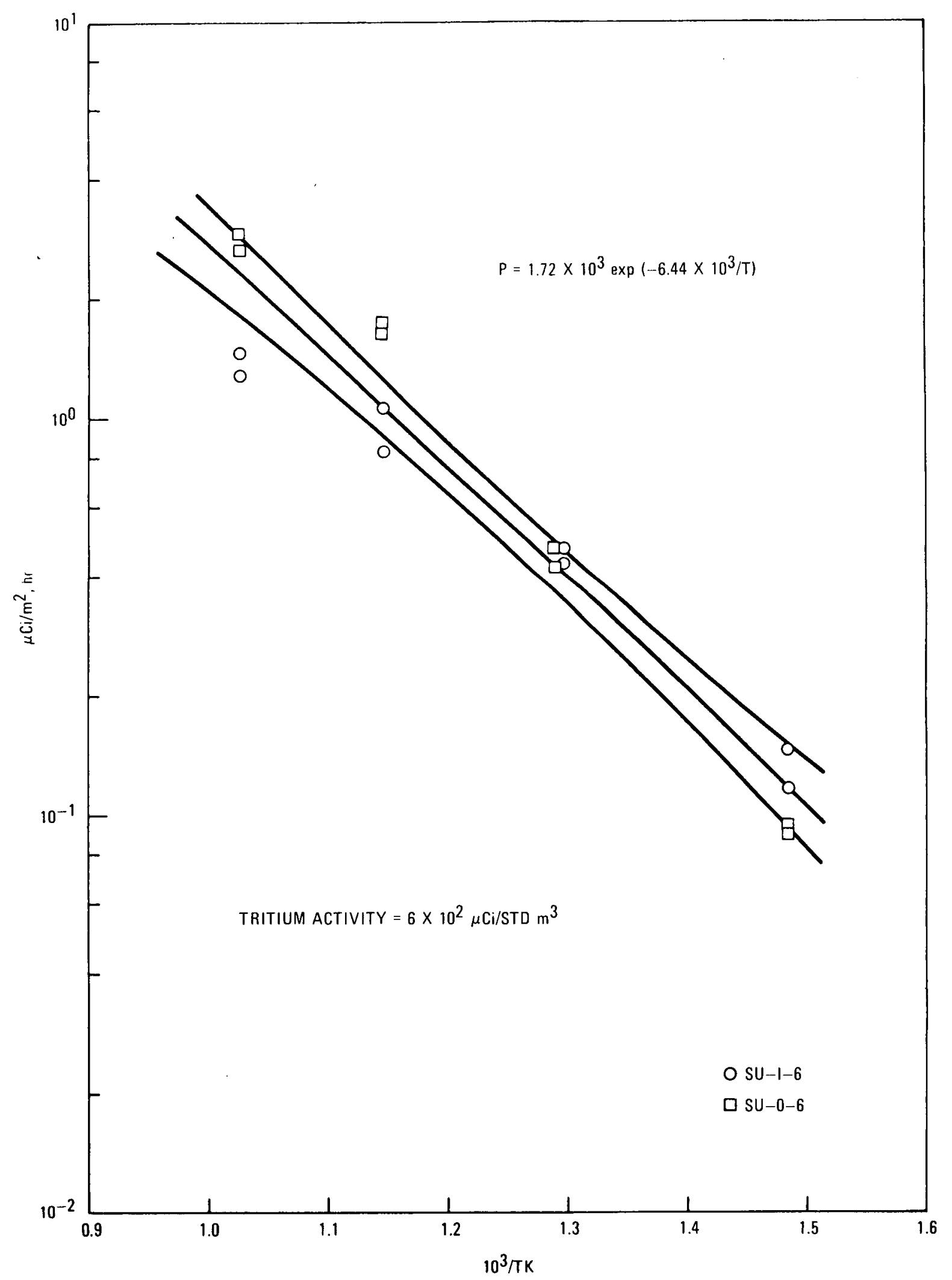

Fig. 6-1. Tritium permeation rates of as-received Peach Bottom superheater samples 


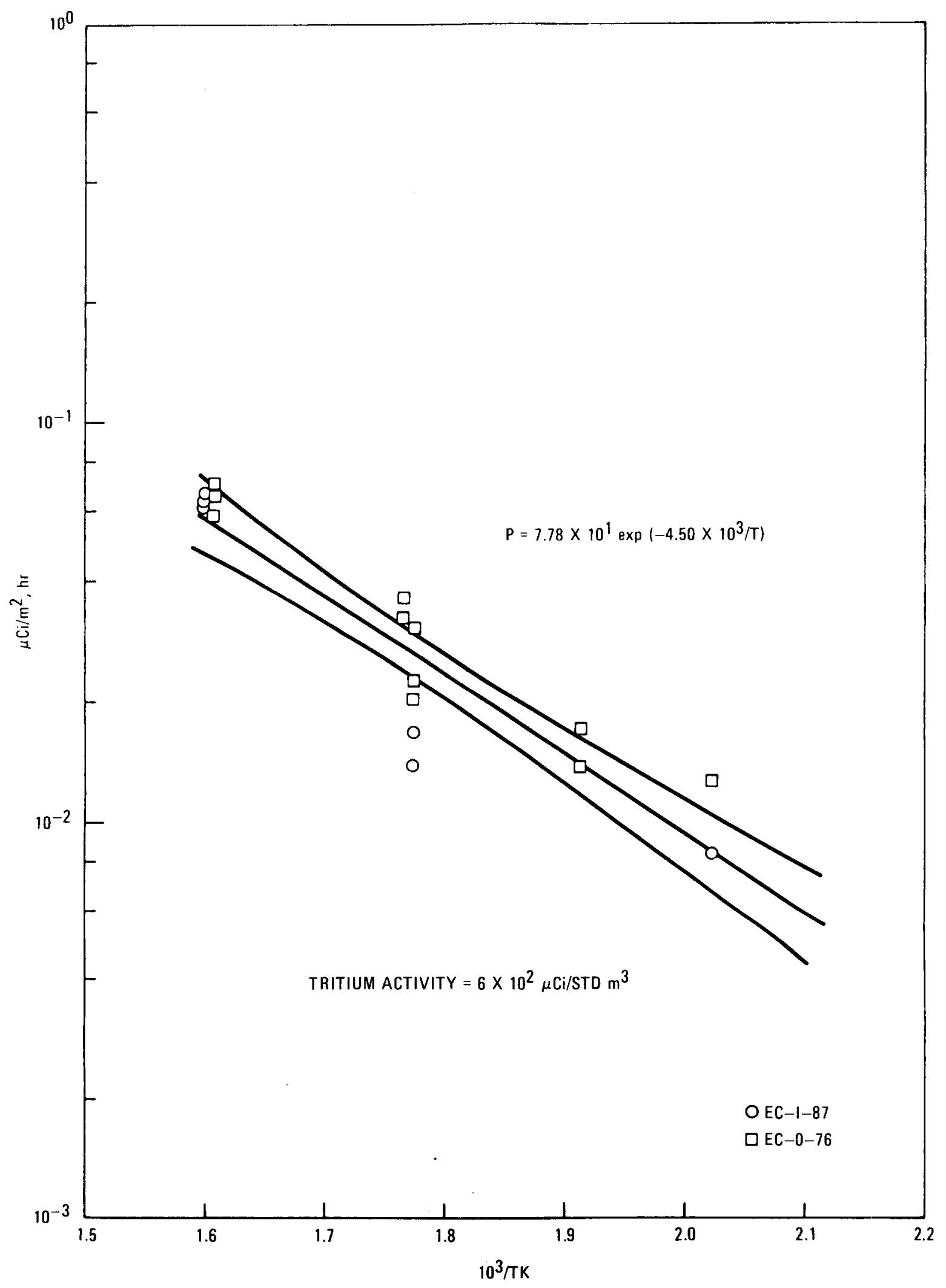

Fig. 6-2. Tritium permeation rates of as-received Peach Bottom economizer, samples 


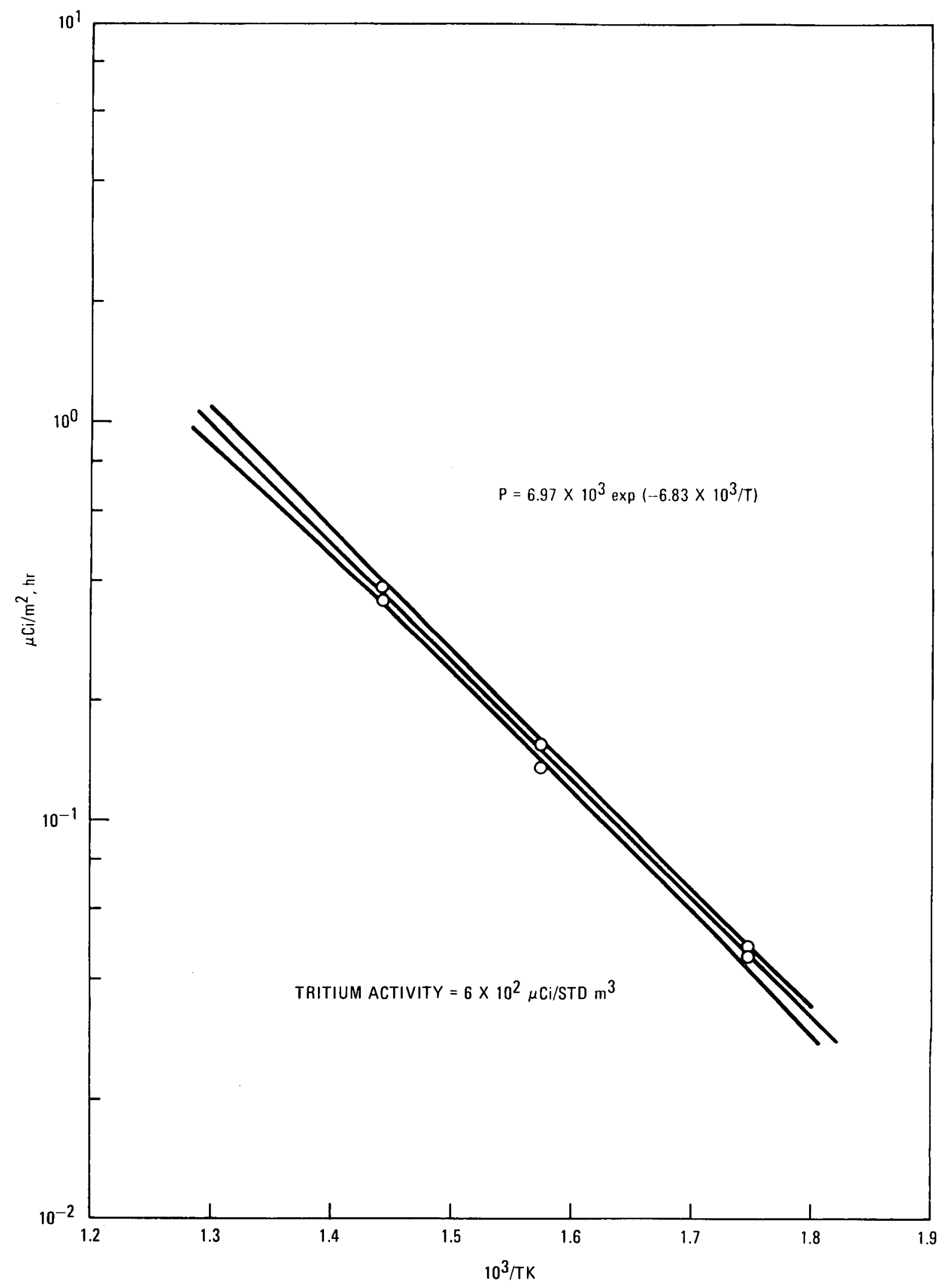

Fig. 6-3. Tritium permeation rates of as-received Peach Bottom evaporator sample EV-I-26 


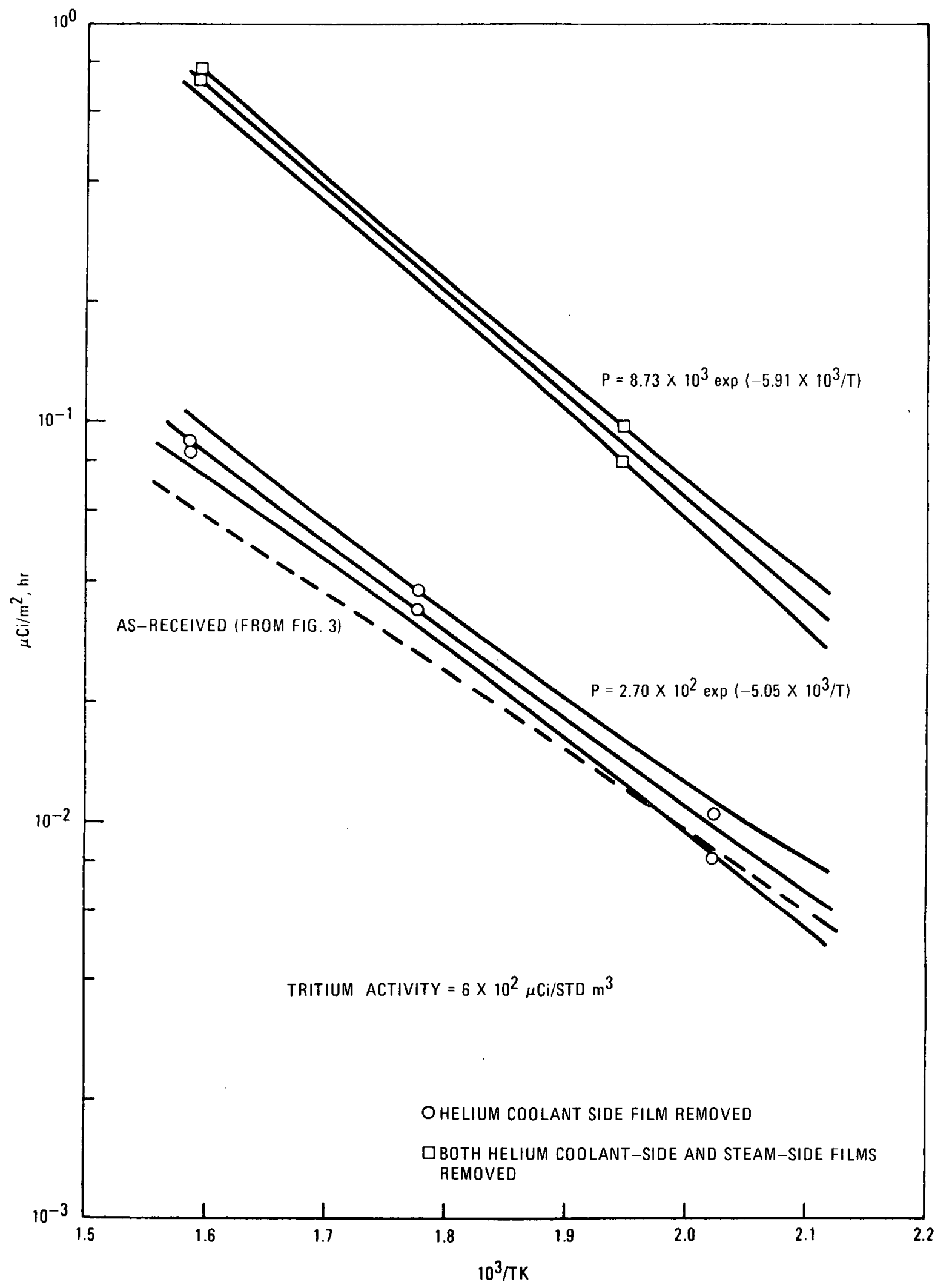

Fig. 6-4. Effect of surface films on tritium permeation rates of Peach Bottom economizer sample EC-0-76 


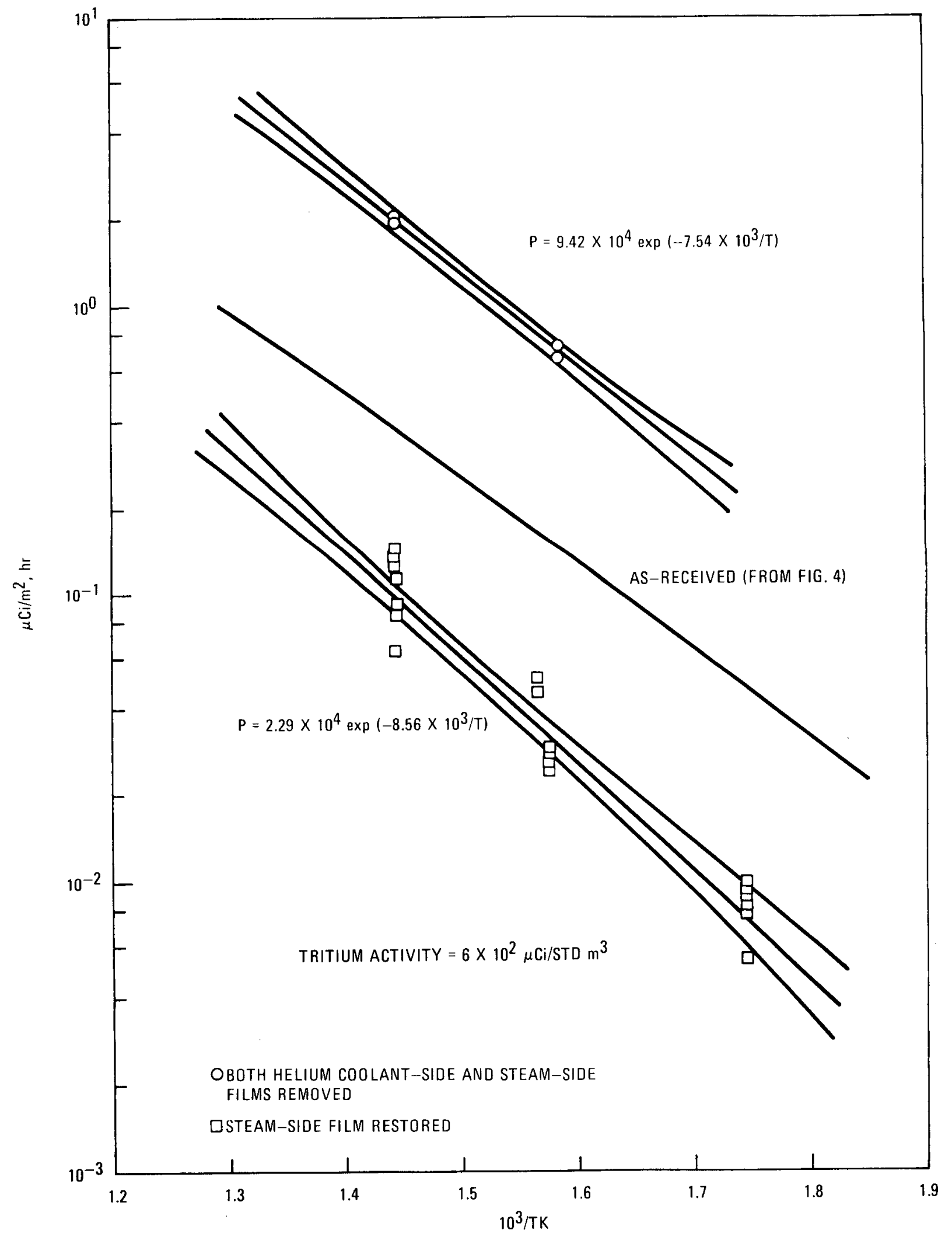

Fig. 6-5. Effect of surface films on tritium permeation rates of Peach Bottom evaporator sample EV-I-26 


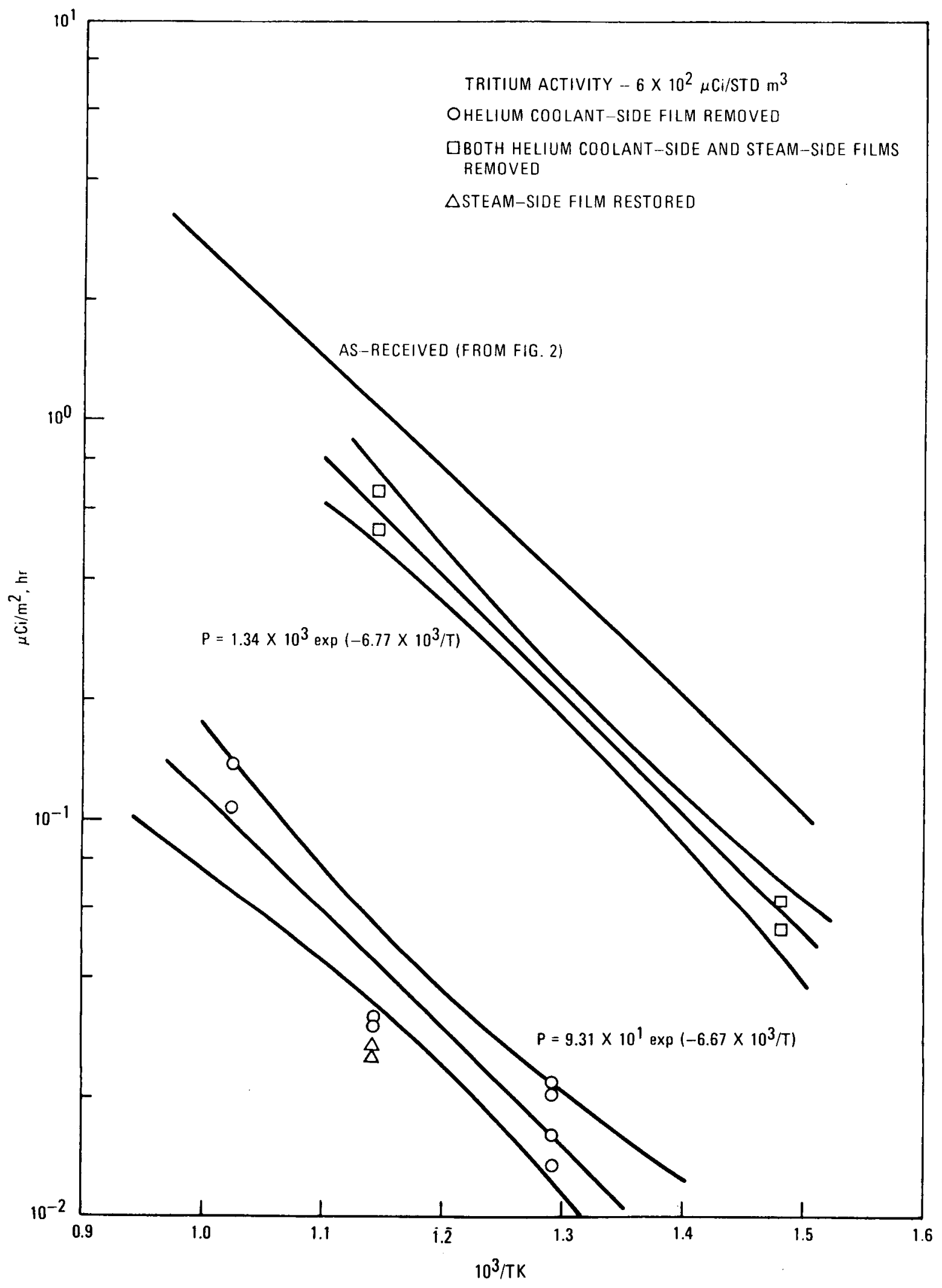

Fig. 6-6. Effect of surface films on tritium permeation rates of Peach Bottom superheater sample SU-I-6 


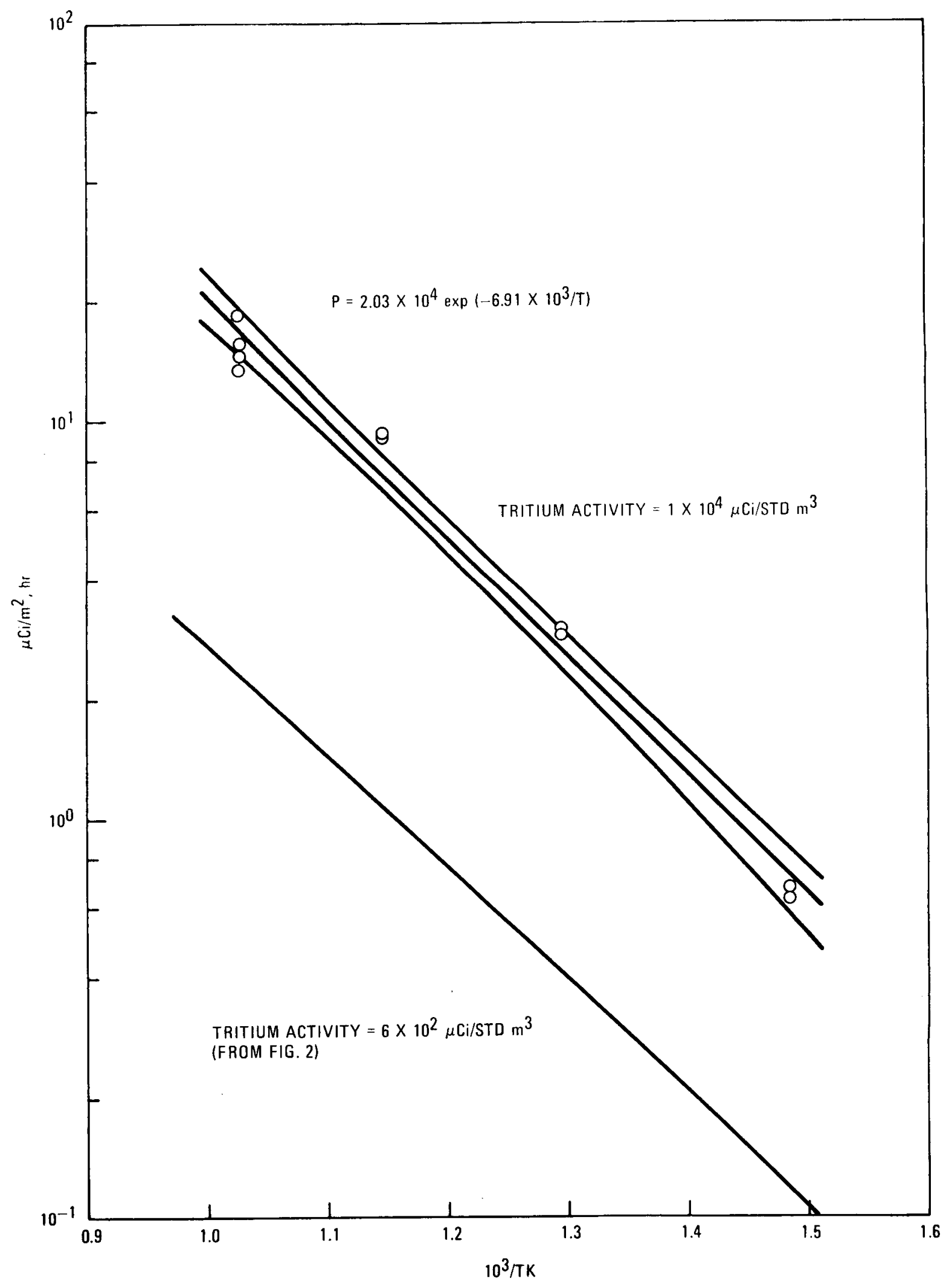

Fig. 6-7. Effect of tritium concentration on tritium permeation rate of as-received Peach Bottom superheater sample SU-0-6 


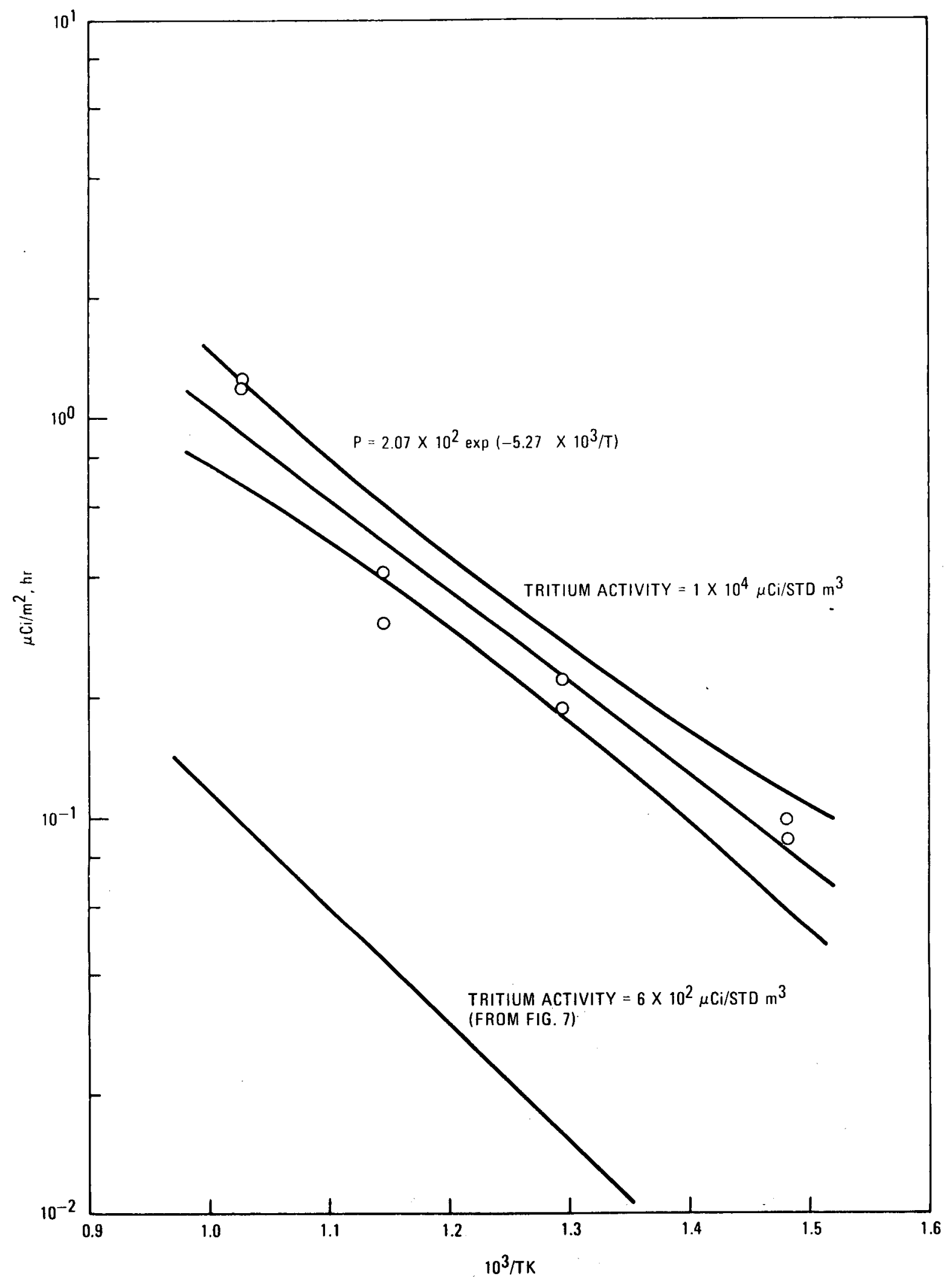

Fig. 6-8. Effect of tritium concentration on tritium permeation rate of Peach Bottom superheater sample SU-I- 6 after the removal of the surface deposit on the helium coolant side 
process if the film is protective, or have no effect on the permeation process if the film is nonprotective. How the removal of the as-received surface film can actually lower the permeation rate needs special explanation. One possible reason for this anomalous observation is that the silicon-lowcarbon steel and the Incoloy-800 can form protective films of much lower tritium permeation rates by reaction with the impurities in the tritium source, and that these highly protective films can be formed only after the as-received carbonaceous films are removed. Measurements of tritium permeation rates as a function of impurity contents in the tritium source are beyond the scope of this work; however, they should be included in any future work on tritium permeation studies.

\subsection{EFFECT OF SURFACE FILMS ON STEAM SIDE}

For all three types of samples studied, the surface films on the steam side showed large effects on tritium permeation rate (see Figs. 6-4, 6-5, and 6-6). For the low-carbon-steel economizer sample EC-0-76, the steel evaporator sample EV-I-26, and the Incoloy-800 superheater sample SU-I-6, the hydrogen treatment of the surfaces of these samples on the steam side resulted in an increase of tritium permeation rates by factors of 6,15 , and 10 , respectively.

\subsection{EFFECT OF TRITIUM CONCENTRATION}

For the two Incoloy-800 superheater samples SU-0-6 and SU-I-6, the tritium permeation rates were measured by using tritium sources of both simulated Peach Bottom coolant composition and large HTGR coolant composition (see Table 5-1). The results showed that the increase of tritium permeation rate with tritium concentration obeys neither the linear nor the square root relationship. For sample SU-0-6, which had the surface films on the helium-coolant side in the as-received state, the increase of tritium source activity by a factor of about 17 (from $6 \times 10^{3}$ to $1 \times 10^{4}$ $\mu \mathrm{Ci} / \mathrm{std} \mathrm{m}^{3}$ ) increased the tritium permeation rate by a factor of about 6 (see Fig. 6-7). For sample SU-I-6, from which the helium-coolant-side surface film was removed, the tritium permeation rate increased by a factor of about 10 for the same change in tritium source activity (see Fig. 6-8). 


\subsection{COMPARISON OF CALCULATED WITH OBSERVED RATE OF TRITIUM RELEASE TO ENVIRONMENT FROM PEACH BOTTOM REACTOR}

The external surface areas and the operating temperature ranges for the three sections of the two Peach Bottom steam generators are (Ref. 5):

$\begin{array}{ll}\text { Economizer } & 212 \mathrm{~m}^{2}, 513 \mathrm{k}-593 \mathrm{~K} \\ \text { Evaporator } & 474 \mathrm{~m}^{2}, 593 \mathrm{~K}-618 \mathrm{~K} \\ \text { Superheater } & 275 \mathrm{~m}^{2}, 693 \mathrm{~K}-853 \mathrm{~K}\end{array}$

By assuming a linear temperature distribution in surface temperature, the tritium release rate for each section was calculated from the measured tritium permeation rates shown in Figs. 6-1 through 6-3 by graphical integration. The results are shown in Table 6-4. The calculated total release is $1.28 \mathrm{Ci}$ per year, which is in good agreement with the observed value of about $1 \mathrm{Ci}$ per year (Ref. 3). It is also interesting to see that a major part of the release is contributed by the superheater section.

The same calculations were performed by using the tritium permeation rates measured after the removal of the black surface films on the heliumcoolant side (Figs. 6-4 through 6-6). The results obtained (see Table 6-5) represent the tritium release rates from the Peach Bottom reactor if there were no black carbonaceous deposits formed on the steam generator surfaces. It can be seen that the total release rate is eight times lower than that shown in Table 6-4 and that the superheater is no longer the major contributor to the total release. The release from the economizer section is about the same as that shown in Table 6-4 but the releases from the evaporator and the superheater sections are much lower. As described previously, in Section 6.2, a possible explanation for the lower release is that in the absence of the porous carbonaceous surface deposits, the impurities in the tritium source can form portective surface films of low tritium permeation rates. 
TABLE 6-4

CALCULATED PEACH BOTTOM TRITIUM RELEASE RATE

(Helium coolant-side surface films in the as-received conditions)

\begin{tabular}{c|c|c}
\hline Section & $\begin{array}{c}\text { Tritium Release } \\
\text { Rate } \\
\text { (curie/year) }\end{array}$ & $\begin{array}{c}\text { Percent of Total } \\
\text { Release Rate }\end{array}$ \\
\hline Economizer & 0.04 & 3 \\
Evaporator & 0.34 & 27 \\
Superheater & 0.90 & 70 \\
Total & 1.28 & \\
\hline
\end{tabular}


TABLE 6-5

CALCULATED PEACH BOTTOM TRITIUM RELEASE RATE

(No black surface films on helium coolant side of steam generator tubes)

\begin{tabular}{l|c|c}
\hline Section & $\begin{array}{c}\text { Tritium Release } \\
\text { Rate } \\
\text { (curie/year) }\end{array}$ & $\begin{array}{c}\text { Percent of Total } \\
\text { Release Rate }\end{array}$ \\
\hline Economizer & 0.048 & 32 \\
Evaporator & 0.066 & 44 \\
Superheater & $\underline{0.036}$ & 24 \\
Total & 0.15 & \\
\hline
\end{tabular}


The results obtained in this work indicate that the permeation of tritium through HTGR steam generator tubes is strongly affected by the surface conditions of the tubes. While the surface films formed on the steam side always reduce the tritium permeation rate, the effect of surface films formed on the helium-coolant side is unclear. The variation of tritium permeation rate with tritium activity in the helium coolant does not seem to follow any simple relationship and could very well depend upon the surface conditions of the steam generator tubes.

The usefulness of the results shown in Figs. 6-7 and 6-8 for predicting tritium release from a large HTGR core therefore depends upon the nature of the surface film formed on the Incoloy-800 superheater during large HTGR operation. The data shown in Fig. 6-7 is useful, assuming the surface film formed is similar to that present on the Peach Bottom superheater during reactor operation. On the other hand, if a more protective surface film is formed with the impurities in the helium coolant, then the tritium permeation rate might be closer to that shown in Fig. 6-8 than that shown in Fig. 6-7. These results show that, in order to quantitatively predict tritium release rates in an operating large HTGR, experimental information on the nature of the superheater surface is needed. 


\section{REFERENCES}

1. Yang, L., and R. E. Bruce, "Calculations of Tritium Permeation Rates Through HTGR Heat Exchangers," General Atomic Company, unpublished data, September 4, 1974.

2. Perry, C. A., "Tritium Diffusion in the Fulton Power P1ants," General Atomic Company, unpublished data, Apri1 3, 1973.

3. Scheffel, W. J., N. L. Baldwin, and R. W. Tomlin, "Operating History Report for the Peach Bottom HTGR," v. I, ERDA Report GA-A13907, General Atomic Company, August 31, 1976.

4. Perry, C. A., "Tritium DV and S Program," General Atomic Company, unpublished data, April 18, 1973.

5. C. F. Braun \& Co., "Design Report for Peach Bottom Steam Generator," Section A, p. 2, September 5, 1961. 